DOE/ID-22207

Prepared in cooperation with the U.S. Department of Energy

Laboratory-Measured and Property-Transfer Modeled Saturated Hydraulic Conductivity of Snake River Plain Aquifer Sediments at the Idaho National Laboratory, Idaho

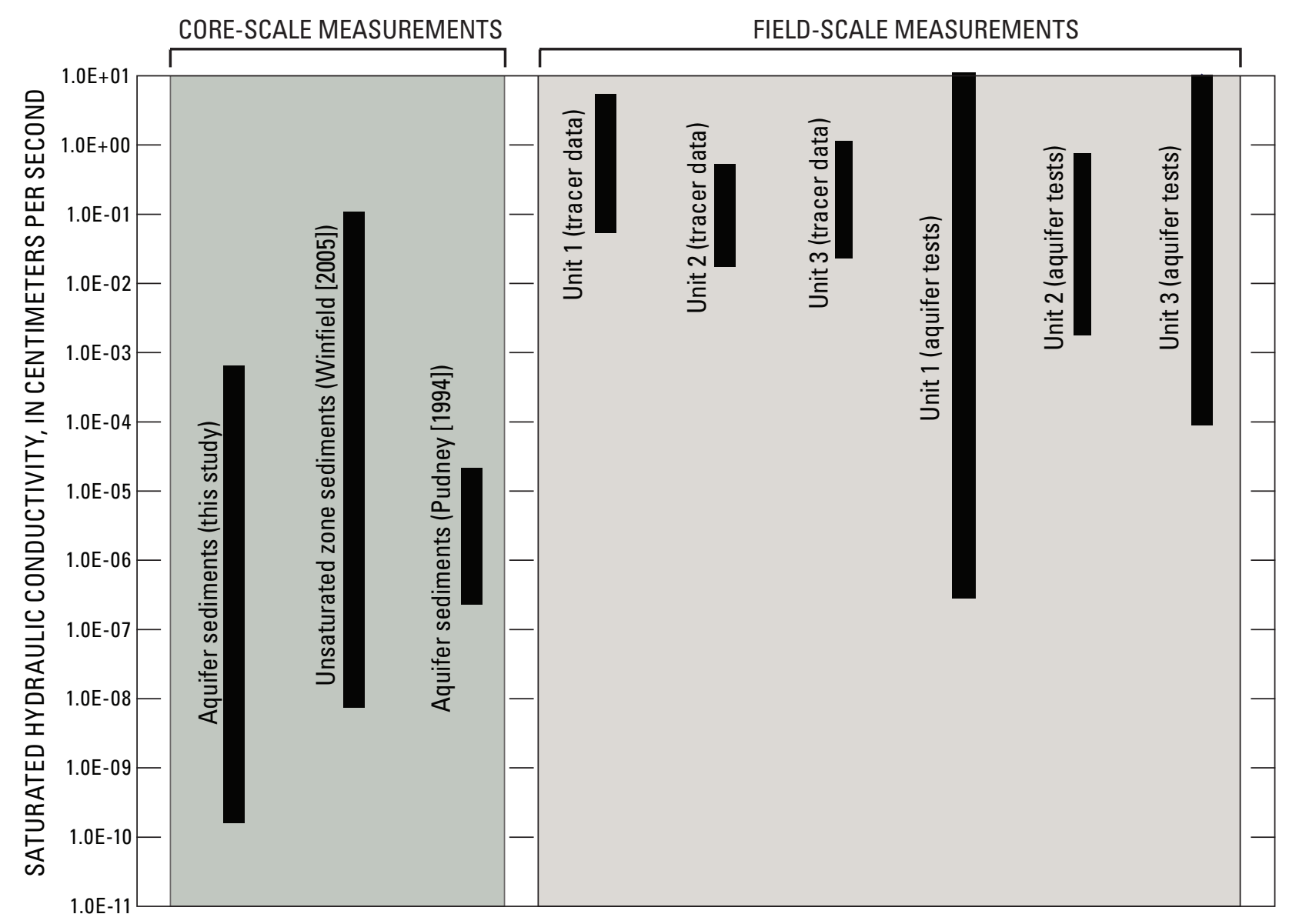

Scientific Investigations Report 2008-5169 
Cover: Graph showing ranges in saturated hydraulic conductivity for aquifer sediments from laboratory and field measurements. 


\section{Laboratory-Measured and Property-Transfer Modeled Saturated Hydraulic Conductivity of Snake River Plain Aquifer Sediments at the Idaho National Laboratory, Idaho}

By Kim S. Perkins

Prepared in cooperation with the U.S. Department of Energy

Scientific Investigations Report 2008-5169 


\section{U.S. Department of the Interior DIRK KEMPTHORNE, Secretary}

\section{U.S. Geological Survey \\ Mark D. Myers, Director}

\section{U.S. Geological Survey, Reston, Virginia: 2008}

For product and ordering information:

World Wide Web: http://www.usgs.gov/pubprod

Telephone: 1-888-ASK-USGS

For more information on the USGS--the Federal source for science about the Earth, its natural and living resources, natural hazards, and the environment:

World Wide Web: http://www.usgs.gov

Telephone: 1-888-ASK-USGS

Any use of trade, product, or firm names is for descriptive purposes only and does not imply endorsement by the U.S. Government.

Although this report is in the public domain, permission must be secured from the individual copyright owners to reproduce any copyrighted materials contained within this report.

Suggested citation:

Perkins, K.S., 2008, Laboratory-measured and property-transfer modeled saturated hydraulic conductivity of Snake River Plain aquifer sediments at the Idaho National Laboratory, Idaho: U.S. Geological Survey Scientific-Investigations Report 2008-5169, 14 p. 


\section{Contents}

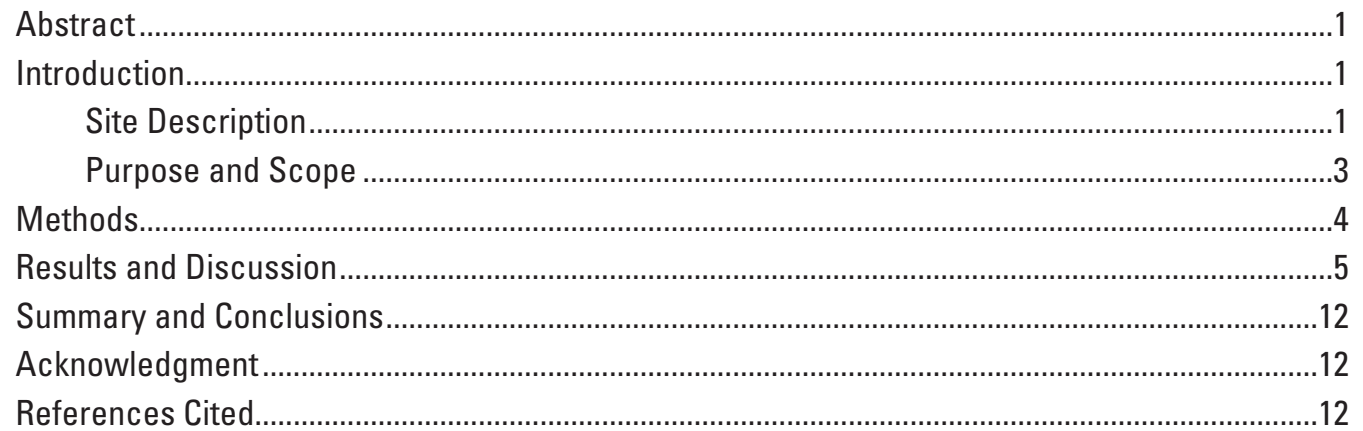

\section{Figures}

Figure 1. Map showing location of the boundary for the subregional scale ground-water flow model, Idaho National Laboratory, Idaho

Figure 2. Map showing locations of boreholes from which core samples were collected for this study, Idaho National Laboratory, Idaho

Figure 3. Diagram showing experimental setup for falling-head, saturated hydraulic conductivity measurements in the laboratory

Figure 4. Graph showing ranges in saturated hydraulic conductivity measured in this study, used in the development of the Winfield (2005) property-transfer model, measured by Pudney (1994), determined based on contaminant movement for units 1-3 (Ackerman and others, 2006), and determined based on aquifer tests for units 1-3 (Ackerman and others, 2006), Idaho National Laboratory, Idaho

Figure 5. Graph showing particle-size distributions for 9 of the 10 core samples, Idaho National Laboratory, Idaho

Figure 6. Graph showing bulk density values for samples from greater than 200 meters depth and less than 60 meters depth, Idaho National Laboratory, Idaho

Figure 7. Graphs showing trends between saturated hydraulic conductivity and (A) bulk density and (B) median particle diameter for the data from this study and Pudney (1994), Idaho National Laboratory, Idaho

Figure 8. Graph showing relation between predicted and observed saturated hydraulic conductivity for the Winfield model, the Pudney model, a linear model fit to the data from this study (linear fit 1), and a linear model fit to the data from this study and the deep samples from Pudney (1994) (linear fit 2), Idaho National Laboratory, Idaho 


\section{Tables}

Table 1. Samples used for measuring saturated hydraulic conductivity, Idaho National Laboratory, Idaho

Table 2. Saturated hydraulic conductivity, bulk density, and particle size statistics for aquifer core samples, Idaho National Laboratory, Idaho

Table 3. U.S. Department of Agriculture textural size classes for 67 bulk aquifer samples, Idaho National Laboratory, Idaho

Table 4. Root-mean-square errors and average errors for the Winfield model, the Pudney model, a linear fit to the core-sample data from this study, and a linear fit to the combined data from this study and the deep core samples from Pudney, Idaho National Laboratory, Idaho

\section{Conversion Factors and Datums}

Conversion Factors

\begin{tabular}{lcl}
\hline \multicolumn{1}{c}{ Multiply } & By & \multicolumn{1}{c}{ To obtain } \\
\hline centimeter $(\mathrm{cm})$ & 0.3937 & inch (in.) \\
centimeter of water $(\mathrm{cm}$-water $)$ & 0.01419 & pound per square inch $\left(\mathrm{lb} / \mathrm{in}^{2}\right)$ \\
centimeter per second $(\mathrm{cm} / \mathrm{s})$ & 0.03281 & foot per second $(\mathrm{ft} / \mathrm{s})$ \\
centimeter per day $(\mathrm{cm} / \mathrm{d})$ & 0.03281 & foot per day $(\mathrm{ft} / \mathrm{d})$ \\
cubic centimeter $\left(\mathrm{cm}^{3}\right)$ & 0.06102 & cubic inch $\left(\mathrm{in}^{3}\right)$ \\
gram $(\mathrm{g})$ & 0.00220 & pounds $(\mathrm{lb})$ \\
gram per centimeter $(\mathrm{g} / \mathrm{cm})$ & 0.00560 & pound per inch $(\mathrm{lb} / \mathrm{in})$ \\
gram per cubic centimeter $\left(\mathrm{g} / \mathrm{cm}^{3}\right)$ & 0.03613 & pounds per cubic inch $\left(\mathrm{lb} / \mathrm{in}^{3}\right)$ \\
kilometer $(\mathrm{km})$ & 0.6214 & mile $(\mathrm{mi})$ \\
meter $(\mathrm{m})$ & 3.281 & foot $(\mathrm{ft})$ \\
millimeter $(\mathrm{mm})$ & 3.937 & inch (in.) \\
square kilometer $\left(\mathrm{km}^{2}\right)$ & 247.1 & acre \\
square kilometer $\left(\mathrm{km}^{2}\right)$ & 0.3861 & square mile $\left(\mathrm{mi}^{2}\right)$ \\
\hline
\end{tabular}

Datums

Vertical coordinate information is referenced to the National Geodetic Vertical Datum of 1929 (NGVD 29).

Horizontal coordinate information is referenced to the North American Datum of 1983 (NAD 83). Altitude, as used in this report, refers to distance above the vertical datum. 


\title{
Laboratory-Measured and Property-Transfer Modeled Saturated Hydraulic Conductivity of Snake River Plain Aquifer Sediments at the Idaho National Laboratory, Idaho
}

\author{
By Kim S. Perkins
}

\section{Abstract}

Sediments are believed to comprise as much as 50 percent of the Snake River Plain aquifer thickness in some locations within the Idaho National Laboratory. However, the hydraulic properties of these deep sediments have not been well characterized and they are not represented explicitly in the current conceptual model of subregional scale groundwater flow. The purpose of this study is to evaluate the nature of the sedimentary material within the aquifer and to test the applicability of a site-specific property-transfer model developed for the sedimentary interbeds of the unsaturated zone. Saturated hydraulic conductivity $\left(K_{\text {sat }}\right)$ was measured for 10 core samples from sedimentary interbeds within the Snake River Plain aquifer and also estimated using the propertytransfer model. The property-transfer model for predicting $K_{\text {sat }}$ was previously developed using a multiple linear-regression technique with bulk physical-property measurements (bulk density $\left[\rho_{\text {bulk }}\right]$, the median particle diameter, and the uniformity coefficient) as the explanatory variables. The model systematically underestimates $K_{\text {sat }}$, typically by about a factor of 10 , which likely is due to higher bulk-density values for the aquifer samples compared to the samples from the unsaturated zone upon which the model was developed. Linear relations between the logarithm of $K_{\text {sat }}$ and $\rho_{\text {bulk }}$ also were explored for comparison.

\section{Introduction}

The subsurface at the Idaho National Laboratory (INL; fig. 1) consists of thick layers of fractured basalt interbedded with thin layers of fluvial, eolian, and lacustrine sediments. These sedimentary interbeds affect vertical and horizontal flow through the saturated and unsaturated zones, although the effect on the regional aquifer flow regime is not well understood. In the current conceptual model of the eastern Snake River Plain (ESRP) aquifer (Ackerman and others, 2006), the overall volume of sediment and basalt is treated as three composite units with effective hydraulic properties that are considered to account for the hydraulic effects of both types of material in combination within each unit. The modeling effort aims to simplify geologic and hydrologic features while retaining those features that are important to water flow and contaminant transport.

Welhan and others (2006) evaluated sediment thickness within the model domain using data from 333 boreholes in and around the INL and determined that within the Big Lost Trough (fig. 1), an area known to have the greatest sediment accumulation, sediment comprises more than 50 percent of the stratigraphic thickness at some locations. The hydrologic significance of this sediment is evident in water-table contours that indicate increased gradients in this area of high sediment accumulation (Joseph Rousseau, U.S. Geological Survey, oral commun., 2007). The hydraulic influence of these units, and hence their importance in the subregional flow model, requires an assessment of the nature of the sedimentary material that would facilitate verification of the model-simulated flow behavior. Vertical gradients observed in the field and those produced by numerical simulation could be verified using knowledge of the hydraulic properties of the sedimentary material. Sediment abundances (Welhan and others, 2006) along with the properties measured in this study provide information useful in model refinement and establish the foundation for an aquifer-specific property-transfer model.

\section{Site Description}

The INL was established in 1949 for nuclear-energy research under the U.S. Atomic Energy Commission (now the U.S. Department of Energy). The INL occupies about 2,300 $\mathrm{km}^{2}$ of the west-central part of the ESRP (fig. 1). The site hosts several facilities of which at least four have been used to generate, store, or dispose of radioactive, organic, and inorganic wastes. The ESRP is a northeast-trending basin, about $320 \mathrm{~km}$ long and $80-110 \mathrm{~km}$ wide, that slopes gently to the southwest and is bordered by northwest-trending mountain ranges. The ESRP is underlain by interbedded volcanic and sedimentary layers that extend as much as 3,000 m below land surface. The sedimentary interbeds, which constitute 
about 15 percent by volume of the unsaturated zone and ESRP aquifer (Anderson and Liszewski, 1997), result from quiet intervals between volcanic eruptions and are of fluvial, eolian, and lacustrine origin. Volcanic units composed primarily of basalt flows, welded-ash flows, and rhyolite, may be vesicular to massive with either horizontal or vertical fracture patterns.

The climate of the ESRP is semiarid and the average annual precipitation is $22 \mathrm{~cm}$. Parts of the ESRP aquifer underlie the INL. The depth to the water table ranges from $60 \mathrm{~m}$ in the northern part of the INL to about $200 \mathrm{~m}$ in the southern part (Barraclough and others, 1981; Liszewski and Mann, 1992). The predominant direction of ground-water flow is from northeast to southwest. Recharge to the aquifer is primarily from irrigation water diversions from streams, precipitation and snowmelt, underflow from tributary-valley streams, and seepage from surface-water bodies (Hackett and others, 1986). Within the INL boundaries, the Big Lost River (fig. 1) is an intermittent stream that flows from southwest to northeast.

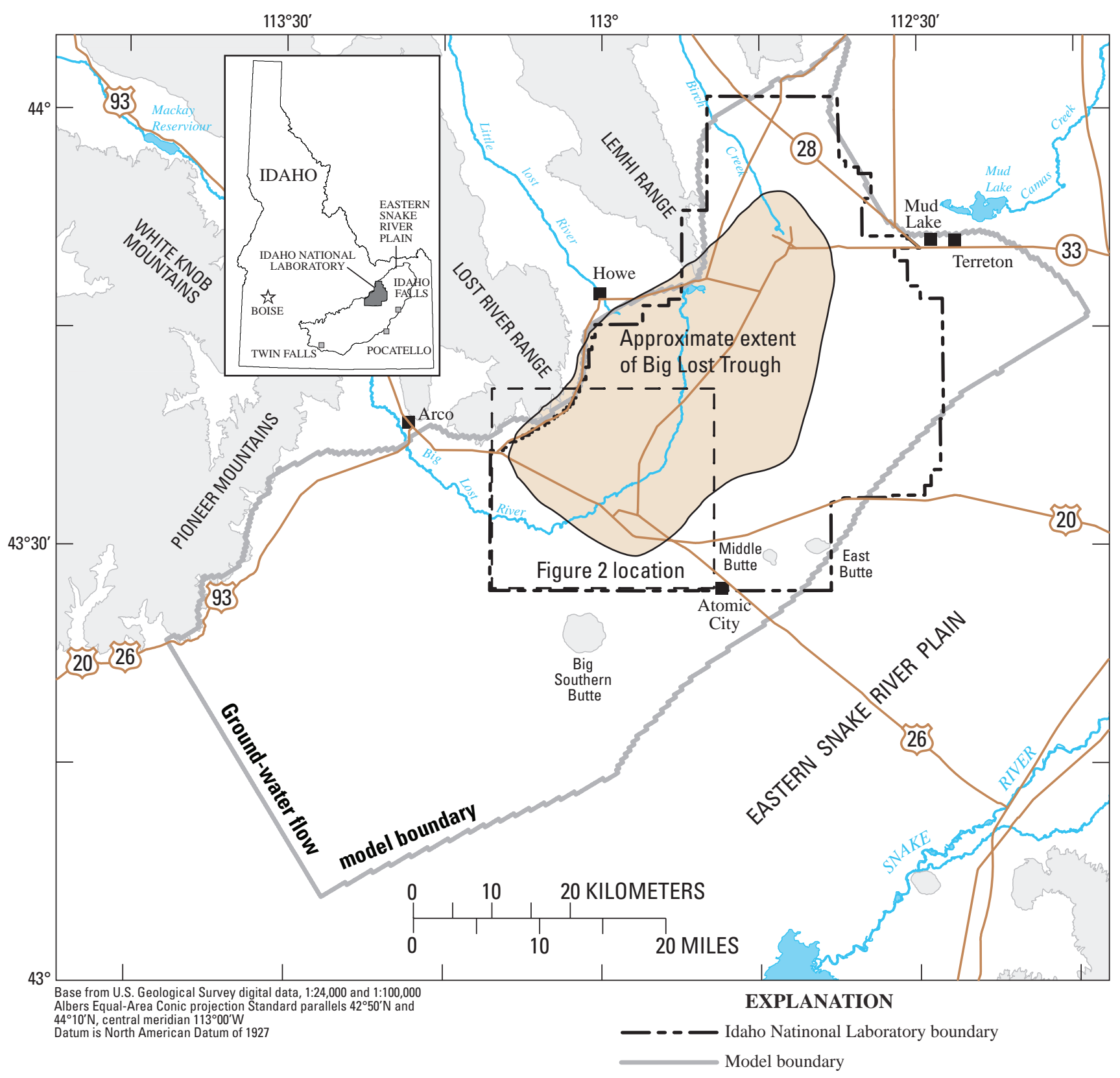

Figure 1. Location of the boundary for the subregional scale ground-water flow model, Idaho National Laboratory, Idaho. 


\section{Purpose and Scope}

This report describes the nature of the sedimentary material within the ESRP aquifer, which will aid in further development of the subregional ground-water flow model. The measurements of saturated hydraulic conductivity $\left(K_{\text {sat }}\right)$ and bulk properties on highly consolidated core samples from the ESRP aquifer and estimates of $K_{\text {sat }}$ based on the sitespecific models developed by Winfield (2005) and Pudney (1994) also are presented. In recent years, numerous deep boreholes have been drilled and core samples obtained which give an opportunity to directly measure $K_{\text {sat }}$ and other relevant properties of sedimentary materials, such as particle-size distribution and bulk density $\left(\rho_{\text {bulk }}\right)$. This report includes $K_{\text {sat }}$ and bulk properties measured on 10 minimally disturbed core samples, and particle size distributions for 77 samples from 4 boreholes within the INL (fig. 2). $K_{\text {sat }}$ also was estimated for all samples using the site-specific property-transfer model of Winfield (2005) and the simple linear relation between the logarithm of $K_{\text {sat }}$ and $\rho_{\text {bulk }}$ identified by Pudney (1994).

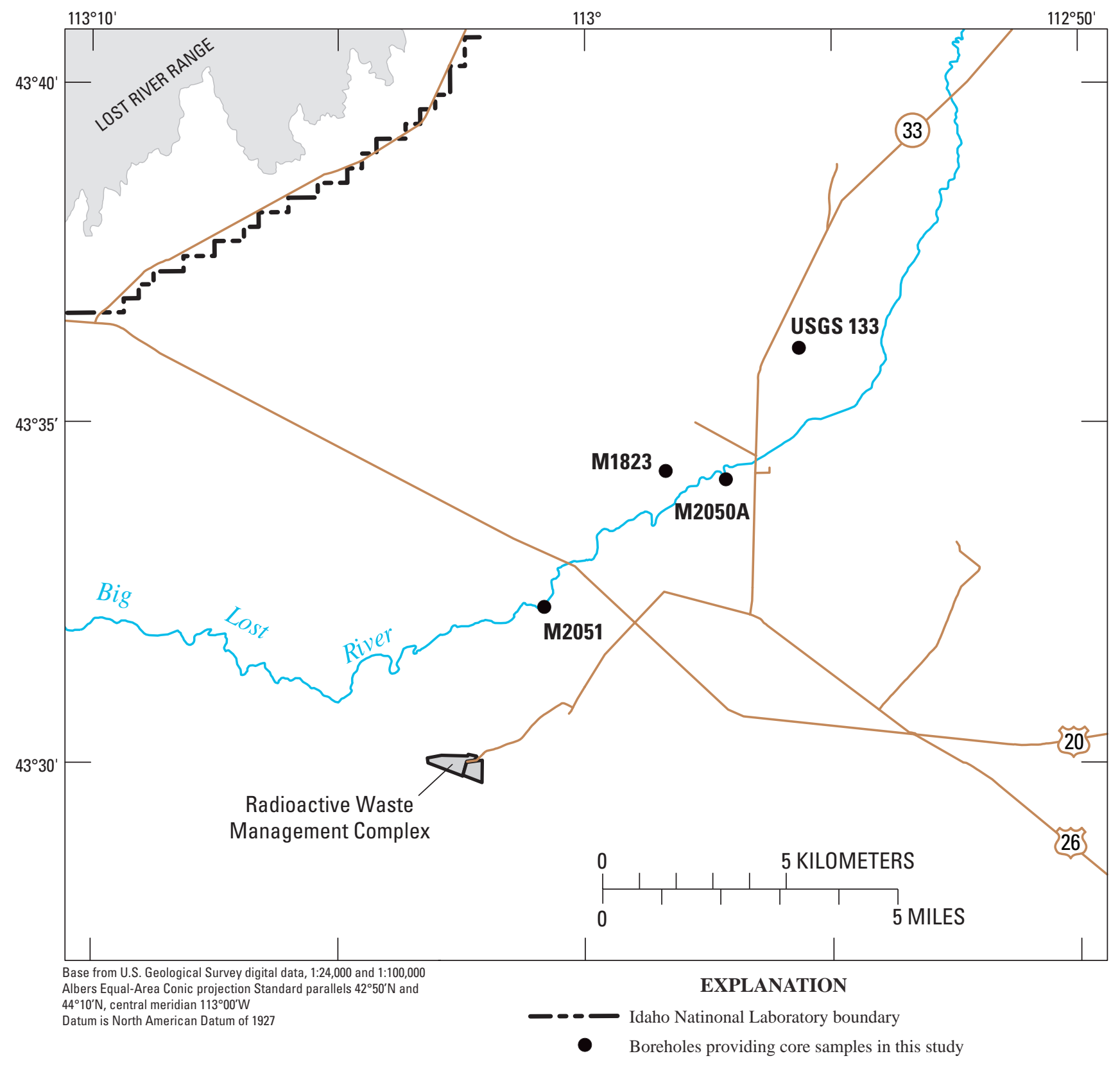

Figure 2. Locations of boreholes from which core samples were collected for this study, Idaho National Laboratory, Idaho. 
The Winfield model uses bulk physical-property data, including $\rho_{\text {bulk }}$ and particle-size statistics [median particle diameter $\left(\mathrm{d}_{50}\right)$ and uniformity coefficient $\left.\left(C_{u}\right)\right]$, to estimate $K_{\text {sat }}$ using a multiple linear-regression equation. Winfield (2005) describes the available data, data selection and processing, multiple linear-regression assumptions and approach, and regression equations. A simple linear relation between $K_{\text {sat }}$ and $\rho_{\text {bulk }}$, as identified by Pudney (1994), also was tested for comparison to the Winfield model. The Pudney (1994) data set includes samples from depths greater than $250 \mathrm{~m}$; whereas, the Winfield (2005) model includes samples from depths less than $80 \mathrm{~m}$.

\section{Methods}

Samples were selected primarily based on condition of the core as well as the representative nature of the material in the overall aquifer profile. Boreholes with available sediment included M1823, M2050a, M2051, and USGS133 (fig. 2). Most core samples were unlined; therefore, a technique was developed to create a liner and water-inflow reservoir as one composite unit that would prevent annular flow along the sample edge during the falling-head measurement of $K_{\text {sat }}$ (fig. 3). The samples were first trimmed carefully using hand

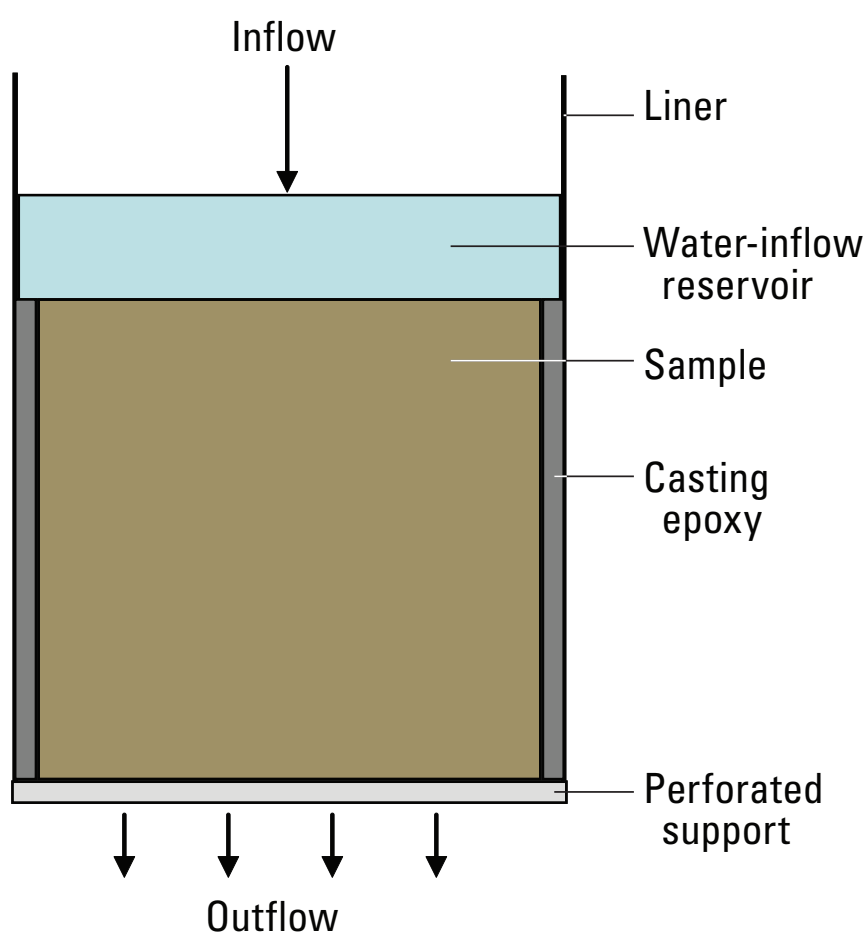

Figure 3. Experimental setup for falling-head, saturated hydraulic conductivity measurements in the laboratory. tools for determination of $\rho_{\text {bulk }}$ where the sample volume must be known ( $\rho_{\text {bulk }}=$ mass of solid/total volume). High-density polyethylene liners, with a diameter several centimeters larger than the core samples, were cut to provide a $5-10 \mathrm{~cm}$ reservoir at the top of the sample. The core samples were placed within the prepared liners and the annular space was filled with a moderately viscous epoxy that could be poured easily, but that would minimally penetrate the sample pore spaces. Before assembly, the liners were abraded on the inner surfaces to ensure good adhesion with the epoxy. Samples used for $K_{\text {sat }}$ measurement are listed in table 1 with a brief visual description.

The standard falling-head method for obtaining $K_{\text {sat }}$ was used for most samples (Reynolds and others, 2002). For samples with low saturated conductivity, inferred a priori based on the time for the sample to saturate completely from the bottom up, a modification of the standard method was performed in a centrifuge with $K_{\text {sat }}$ calculated using the following equation (Nimmo and Mello, 1991; Nimmo and others, 2002):

$$
\begin{aligned}
K_{\text {sat }} & =[(-2 l a) /(A \rho \Delta t g)] \\
& \ln \left[\left(g z_{f}+\omega^{2} r_{\mathrm{b}}{ }^{2}\right) /\left(g z_{\mathrm{i}}+\omega^{2} r_{\mathrm{b}}{ }^{2}\right)\right],
\end{aligned}
$$

where

$l$ is sample length,

$a$ is the cross-sectional area of the inflow reservoir,

$A$ is the cross-sectional area of the sample,

$\rho$ is the density of the fluid used,

$t$ is time,

$g$ is gravitational acceleration,

$z$ is the height of water in the reservoir (initial and final),

$r_{\mathrm{b}}$ is the radius of rotation at the sample bottom, and

$\omega$ is angular speed.

Table 1. Samples used for measuring saturated hydraulic conductivity, Idaho National Laboratory, Idaho.

\begin{tabular}{lcl}
\hline \multicolumn{1}{c}{ Hole } & $\begin{array}{c}\text { Depth } \\
\text { (meters) }\end{array}$ & \multicolumn{1}{c}{ Description } \\
\hline M1823 & 221.4 & brown, silty \\
M1823 & 223.7 & tan with basalt flecks \\
M1823 & 284.0 & orange red, crumbly \\
M2050a & 320.3 & orange red, porous \\
M2050a & 362.7 & orange red, hard \\
M2050a & 396.2 & sandy \\
M2050a & 229.0 & orange red, hard \\
M2051 & 214.5 & orange red, very porous \\
USGS133 & 193.5 & orange red w/basalt gravel \\
USGS133 & 240.9 & brown, silty \\
\hline
\end{tabular}


Errors in measured $K_{\text {sat }}$ values commonly arise from annular flow between the sample and liner (which was eliminated by casting the samples with epoxy), mechanical error, precision of the device used to measure length, and operator error. The calculated maximum error in $K_{\text {sat }}$ due to these effects is about 10 percent (Nimmo and others, 2002).

A Coulter LS-230 Particle Size Analyzer was used to characterize particle-size distributions by optical diffraction (Gee and Or, 2002). The range of measurement for this particular device is $0.04-2,000 \mu \mathrm{m}$, which is divided into $116-\mu \mathrm{m}$ size bins. Any particles greater than $2,000 \mu \mathrm{m}$ were sieved out and later integrated into the size-distribution results. The fraction less than 2,000 $\mu \mathrm{m}$ was disaggregated carefully using a mortar and rubber-tipped pestle, and then split with a 16-compartment spinning riffler to obtain appropriate random samples for analysis. The material was sonicated in suspension for 60 seconds prior to each run; an average of two runs was calculated for each sample.

Two property-transfer models were evaluated in this study. Winfield (2005) formulated the following propertytransfer equation for $K_{\text {sat }}$ using particle-size statistics [median particle diameter $\left(\mathrm{d}_{50}\right)$ and uniformity coefficient $\left.\left(C_{u}\right)\right]$ and $\rho_{\text {bulk }}$ as input:

$$
\begin{aligned}
\log \left(K_{\text {sat }}\right)= & -1.7690+0.0794 \rho_{\text {bulk }} \\
& +1.7507 \log \left(d_{50}\right)-0.3274 \log \left(C_{u}\right) .
\end{aligned}
$$

In an earlier study (Pudney, 1994), the following empirical relation was found between $K_{\text {sat }}$ and $\rho_{\text {bulk }}$ :

$$
\log \left(K_{\text {sat }}\right)=-4.66 \rho_{\text {bulk }}+2.67 \text {. }
$$

The root-mean-square error (RMSE), also referred to as the standard error of the estimate, is used in this study as a goodness-of-fit indicator between measured and estimated $K_{\text {sat }}$ values. The RMSE is calculated as:

$$
\text { RMSE }=\sqrt{\frac{\sum_{j=1}^{n}\left(y_{j}-\hat{y}_{j}\right)^{2}}{n}},
$$

where

$y_{j}$ is the measured value,

$\hat{y}_{j}$ is the estimated value of the dependent variable, and,

nis the number of observations.

Small RMSE values indicate the estimated value is closer to the measured value of the variable. $K_{\text {sat }}$ values span several orders of magnitude, thus, in effect, unequally weighting points in the RMSE calculation. Therefore, the $K_{\text {sat }}$ values were transformed logarithmically prior to calculation.
The average error $(A E)$ also was calculated for comparison to highlight systematic over or under prediction as follows:

$$
A E=\frac{\sum\left(y_{j}-\hat{y}_{j}\right)}{n} .
$$

For the data analyzed here, a negative $A E$ value indicates under estimation and a positive $A E$ value indicates over estimation.

\section{Results and Discussion}

Samples were selected to capture as wide a variety of materials (based on visual inspection) as was practical. Hence, measured core-sample properties were highly variable (table 2). Figure 4 shows the ranges in $K_{\text {sat }}$ values measured in this study compared with those used in the development of the Winfield (2005) property-transfer model and measured by Pudney (1994), and those from Ackerman and others (2006), where horizontal $K_{\text {sat }}$ values for each of the three hydrolgeologic units were estimated. These estimates are from (1) average linear ground-water velocities from numerous studies of atmospheric tracers, long term monitoring of contaminant movement in the aquifer, and knowledge of hydraulic gradients and effective porosities and (2) aquifer tests.

The values determined by Ackerman and others (2006) are much higher generally than the range of values for sediments because they represent the weighted average of sediment and basalt, and reflect a much larger scale of measurement. The ground-water flow model calibration process tends to assign lower values in areas where sediment proportions are greater than 11 percent in the upper part of the aquifer (Welhan and others, 2006). Welhan and others (2006) indicated that a more sophisticated scaling process based on sediment abundance would lead to improved estimates of horizontal $K_{\text {sat }}$ values for the hydrogeologic units. This study provides data for deep aquifer sediments that can be used in scaling the composite $K_{\text {sat }}$ values.

Laboratory-measured $K_{\text {sat }}$ values vary over six orders of magnitude (fig. 4) with an average value of $8.78 \times 10^{-5} \mathrm{~cm} / \mathrm{s}$ and a standard deviation of $1.45 \times 10^{-4}$. The average $\rho_{\text {bulk }}$ was $1.64 \mathrm{~g} / \mathrm{cm}^{3}$ with a standard deviation of 0.28 . One sample from hole M2051 at $214.5 \mathrm{~m}$ depth had an unusually low $\rho_{\text {bulk }}$ value $\left(1.02 \mathrm{~g} / \mathrm{cm}^{3}\right)$ and also the highest measured $K_{\text {sat }}$ value $(4.78 \times$ $\left.10^{-4}\right)$. Excluding this anomalous sample, the average $\rho_{\text {bulk }}$ was $1.71 \mathrm{~g} / \mathrm{cm}^{3}$. The sample from hole M2050a at $362.7 \mathrm{~m}$ depth, which had a low $K_{\text {sat }}$ value $\left(1.25 \times 10^{-9} \mathrm{~cm} / \mathrm{s}\right)$, was too consolidated to be disaggregated for particle-size analysis. 
Table 2. Saturated hydraulic conductivity, bulk density, and particle size statistics for aquifer core samples, Idaho National Laboratory, Idaho.

[Abbreviations: $\mathrm{m}$, meter; $\mathrm{cm} / \mathrm{s}$, centimeter per second; $\mathrm{g} / \mathrm{cm}^{3}$, gram per cubic centimeter; $\mathrm{mm}$, millimeter; $K_{\text {sar }}$, saturated hydraulic conductivity; $d_{50}$, uniformity coefficient]

\begin{tabular}{|c|c|c|c|c|c|c|c|}
\hline Hole & $\begin{array}{l}\text { Depth } \\
\text { (m) }\end{array}$ & Description & $\begin{array}{c}K_{\text {sat }} \\
(\mathrm{cm} / \mathrm{s})\end{array}$ & $\begin{array}{c}\text { Bulk density } \\
\left(\mathrm{g} / \mathrm{cm}^{3}\right)\end{array}$ & $\begin{array}{c}\text { Mean particle } \\
\text { diameter } \\
(\mathrm{mm})\end{array}$ & $\begin{array}{l}\text { Standard } \\
\text { deviation }\end{array}$ & $\begin{array}{c}\text { Median particle } \\
\text { diameter } \\
\left(d_{50}, \mathrm{~mm}\right)\end{array}$ \\
\hline M1823 & 223.7 & tan, basalt flecks & $6.38 \times 10^{-6}$ & 1.68 & 0.013 & 0.005 & 0.018 \\
\hline M1823 & 284.0 & oxidized, crumbly & $2.54 \times 10^{-5}$ & 1.72 & 0.093 & 0.007 & 0.111 \\
\hline M2050a & 396.2 & sandy & $1.32 \times 10^{-4}$ & 1.66 & 0.088 & 0.005 & 0.160 \\
\hline M2050a & 229.0 & oxidized, hard & $2.07 \times 10^{-10}$ & 1.77 & 0.032 & 0.004 & 0.052 \\
\hline M2051 & 214.5 & oxidized, very porous & $4.78 \times 10^{-4}$ & 1.02 & 0.052 & 0.004 & 0.063 \\
\hline USGS133 & 193.5 & oxidized w/basalt gravel & $6.13 \times 10^{-5}$ & 1.85 & 0.152 & 0.006 & 0.178 \\
\hline
\end{tabular}

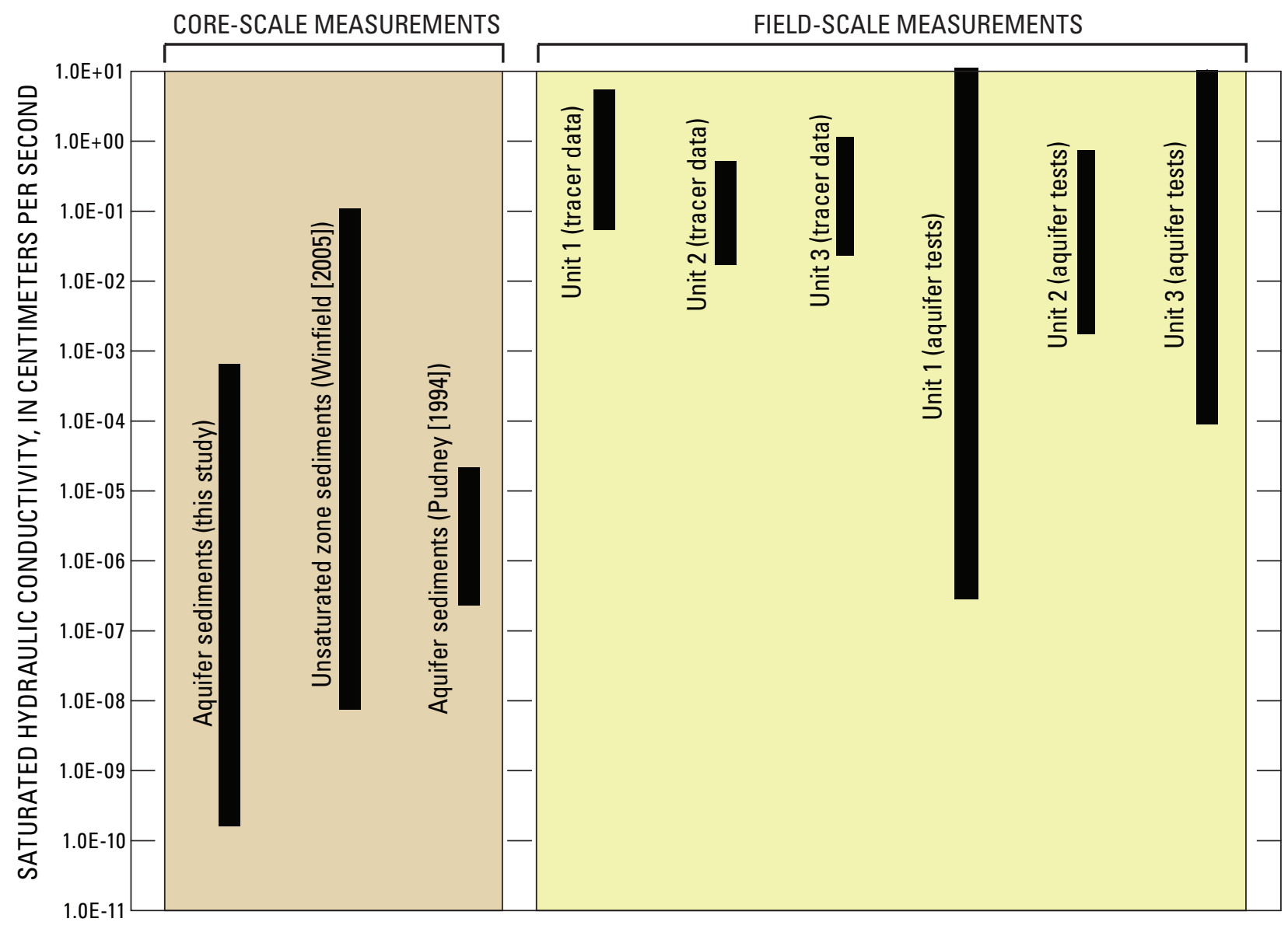

Figure 4. Ranges in saturated hydraulic conductivity measured in this study, used in the development of the Winfield (2005) property-transfer model, measured by Pudney (1994), determined based on contaminant movement for units 1-3 (Ackerman and others, 2006), and determined based on aquifer tests for units 1-3 (Ackerman and others, 2006), Idaho National Laboratory, Idaho. 
Particle-size distributions for nine of the core samples are shown in figure 5 . Particle-size classes are listed in table 3 for the additional 67 bulk samples.

$K_{\text {sat }}$ values for the 78 unsaturated zone sedimentary interbed samples used by Winfield (2005) in model development ranged from $1.1 \times 10^{-8}$ to $8.2 \times 10^{-2} \mathrm{~cm} / \mathrm{s}$ with an average $\rho_{\text {bulk }}$ of $1.46 \mathrm{~g} / \mathrm{cm}^{3}$ (fig. 4). $K_{\text {sat }}$ values for the seven deep samples used by Pudney (1994) ranged from $3.0 \times 10^{-7}$ to $1.4 \times 10^{-5} \mathrm{~cm} / \mathrm{s}$ with an average $\rho_{\text {bulk }}$ of $1.85 \mathrm{~g} / \mathrm{cm}^{3}$ (fig. 4 ). Generally, $K_{\text {sat }}$ values, as well as particle size statistics, show no consistent trend with depth; however, deeper interbeds tend to have higher $\rho_{\text {bulk }}$ values. Figure 6 shows the difference in $\rho_{\text {bulk }}$ values for deep samples (greater than $200 \mathrm{~m}$ depth from this study and Pudney 1994), and shallow samples (less than $60 \mathrm{~m}$ depth from Perkins and Nimmo, 2000; Perkins, 2003; and Winfield, 2003). The Man-Whitney rank-sum test (Zar, 1996) was used to determine that the difference in $\rho_{\text {bulk }}$ between the shallow and deep samples statistically is significant. The calculated test statistic $(Z)$ was 5.488 , compared with the critical two-tailed value of 1.645 with an $\alpha$ level of 0.05 . The samples from greater than $200 \mathrm{~m}$ depth indicate no strong linear trends between $K_{\text {sat }}$ and bulk properties ( $\rho_{\text {bulk }}$ and median particle diameter); however, regression trends are slightly stronger for the Pudney (1994) data set than the data set from this study (ig. 7).

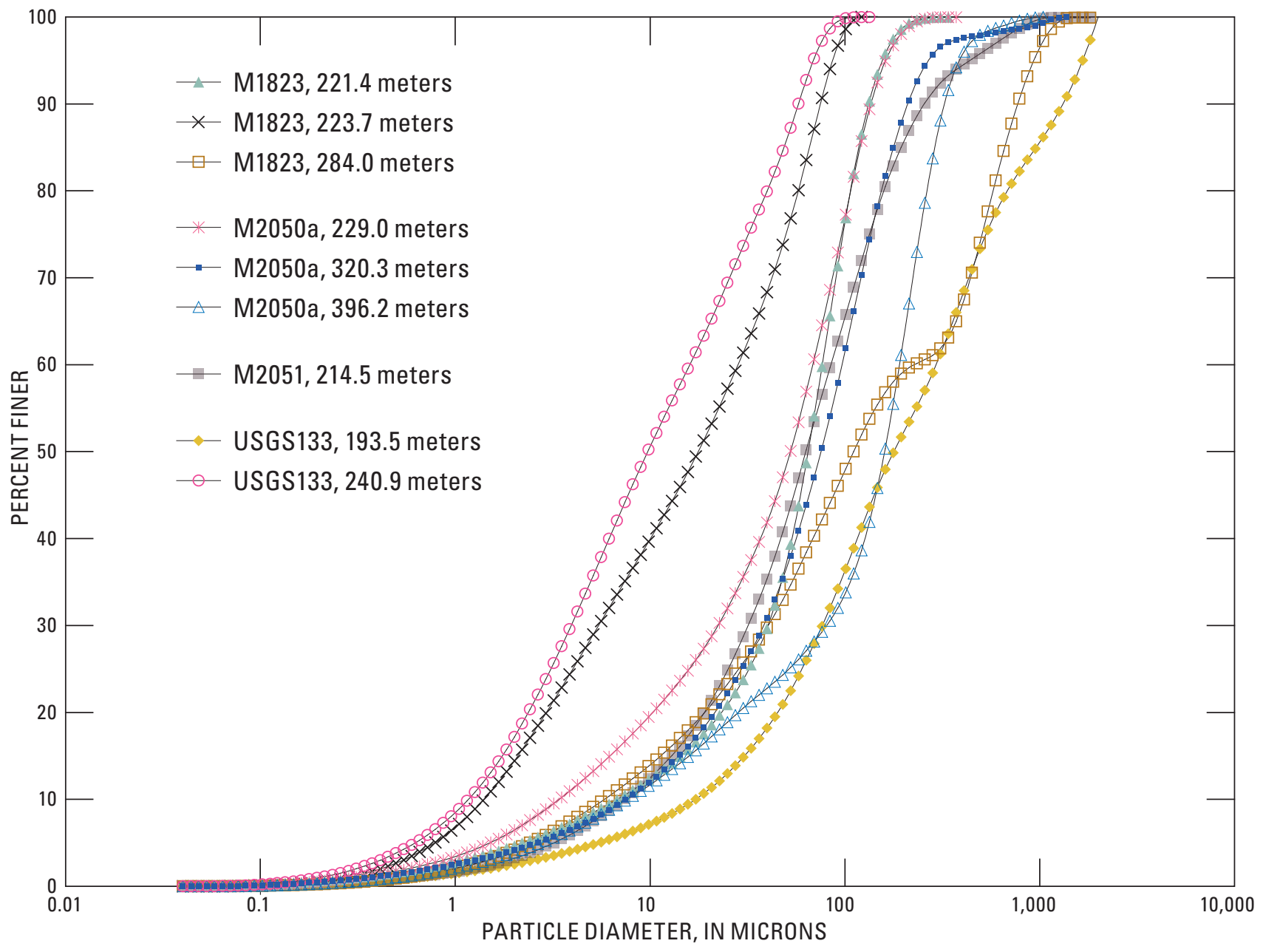

Figure 5. Particle-size distributions for 9 of the 10 core samples, Idaho National Laboratory, Idaho. 
Table 3. U.S. Department of Agriculture textural size classes for 67 bulk aquifer samples, Idaho National Laboratory, Idaho.

[Abbreviations: m, meter; $\mu \mathrm{m}$, micrometer; mm, millimeter. Symbols: $<$, less than; >, greater than]

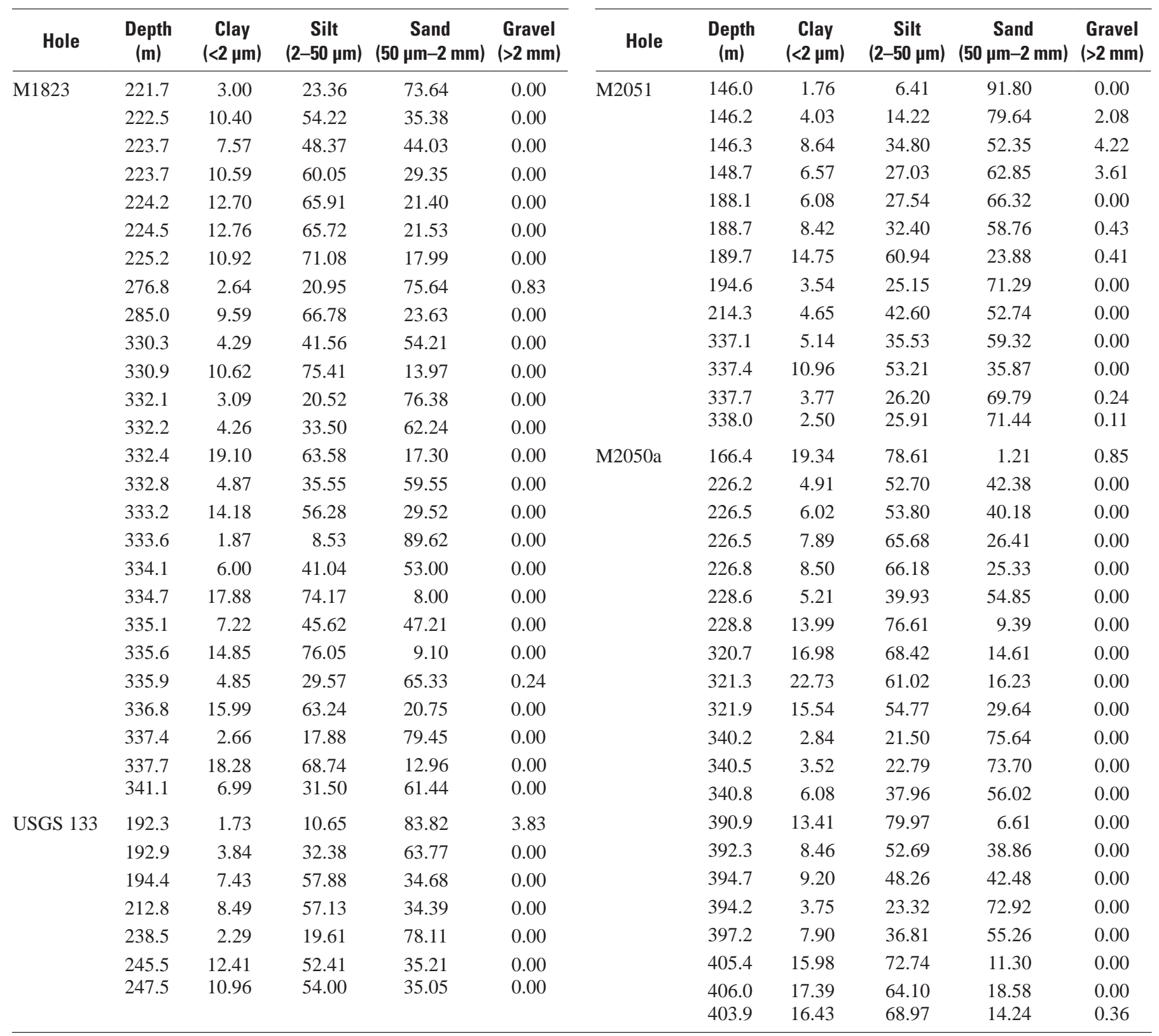




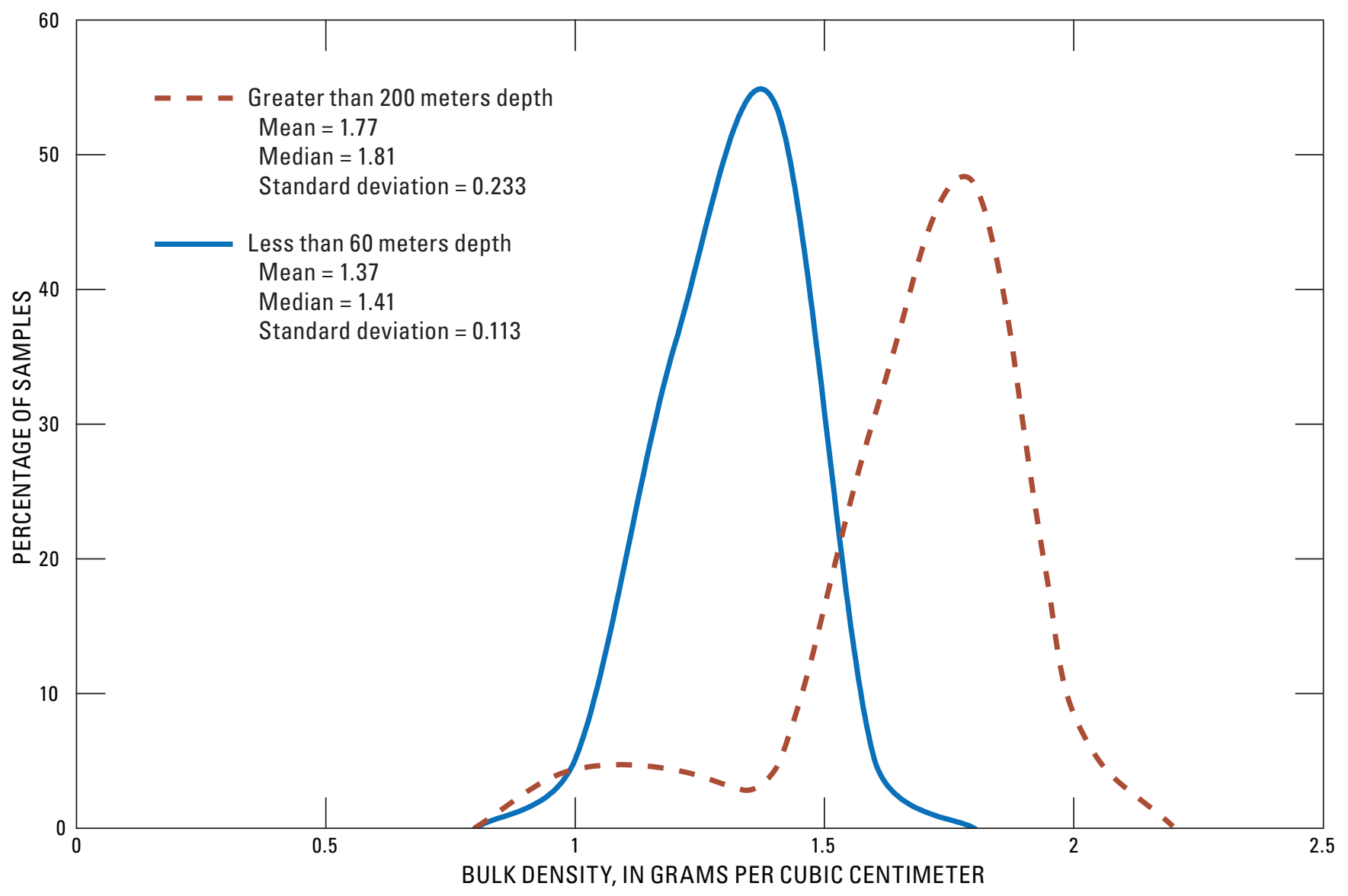

Figure 6. Bulk density values for samples from greater than 200 meters depth and less than 60 meters depth, Idaho National Laboratory, Idaho. 

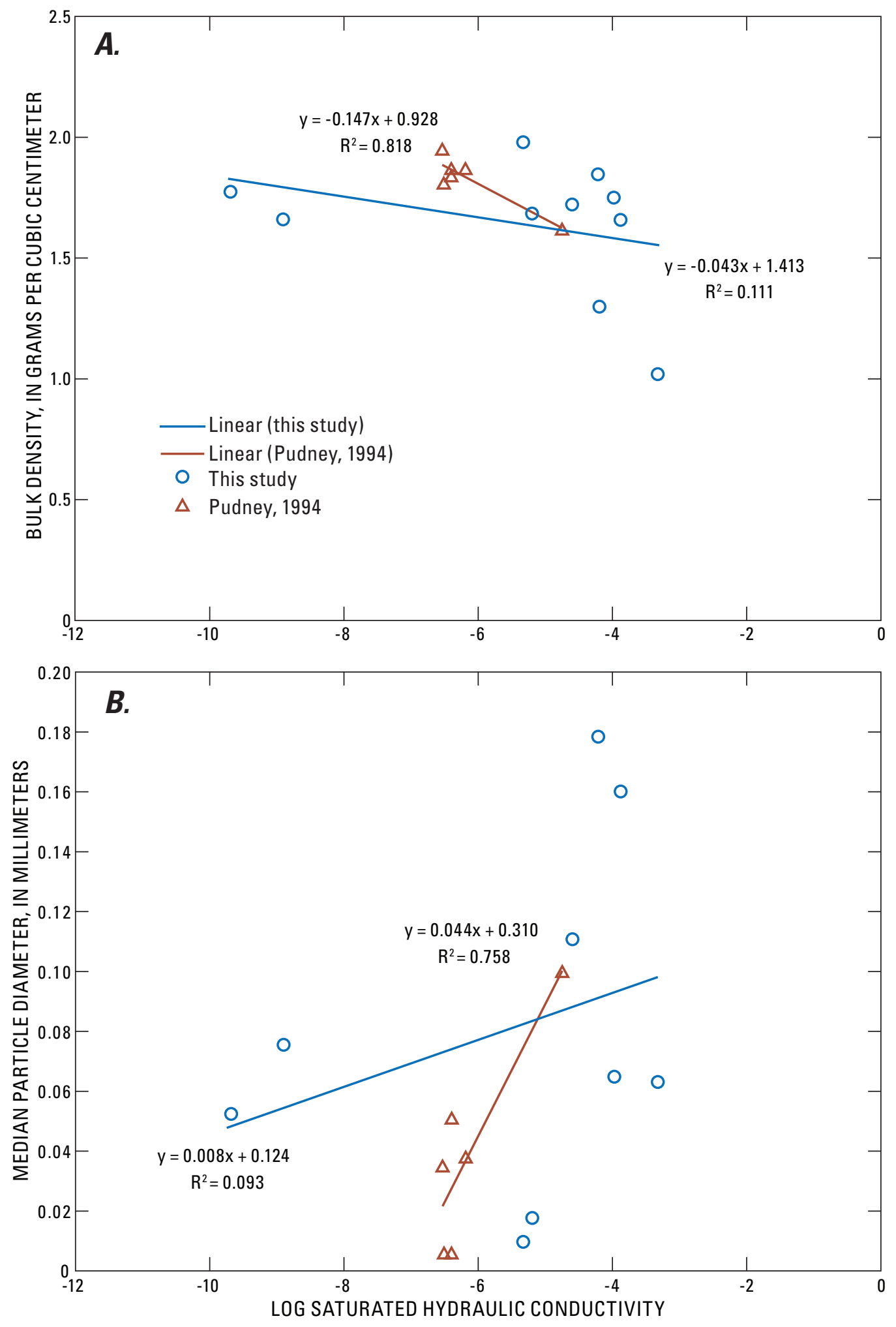

Figure 7. Trends between saturated hydraulic conductivity and (A) bulk density and (B) median particle diameter for the data from this study and Pudney (1994), Idaho National Laboratory, Idaho. Lines represent ordinary least-squares linear fits to the data. 
As shown in figure 8, with the exception of the lowest measured value, the Winfield model under predicts $K_{\text {sat }}(A E$ value of -0.1110). The Pudney model (based on a combination of surficial and deep samples) over and under predicts about equally (fig. 8) with slightly more under predictions (AE value of -0.0009). Also shown in figure 8 are the predictions based on a linear fit to the $K_{\text {sat }}$ and $\rho_{\text {bulk }}$ data for the 10 core samples used in this study (labeled linear fit 1 ) and a linear fit to the data from this study combined with the 7 deep samples (labeled linear fit 2) from Pudney (1994). The small measurement error associated with the $K_{\text {sat }}$ values (about 10 percent) has no influence on the relations examined here; error bars are imperceptible on figure 8. As listed in table 4, a linear fit to all available data from greater than $200 \mathrm{~m}$ gives the lowest RMSE value result, slightly lower than the Winfield and Pudney models. Predictions from the linear fit to the $K_{\text {sat }}$ and $\rho_{\text {bulk }}$ data for the 10 core samples from this study gives the highest RMSE value. The systematic under prediction by the Winfield model indicates that an adjustment could be made for samples with higher $\rho_{\text {bulk }}$ or other systematic differences. Because the aquifer samples are affected by different processes by virtue of being deep as well as saturated, the addition of explanatory variables that include mechanical, chemical, and mineralogical parameters might yield better predictions.

Table 4. Root-mean-square errors and average errors for the Winfield model, the Pudney model, a linear fit to the core-sample data from this study, and a linear fit to the combined data from this study and the deep core samples from Pudney, Idaho National Laboratory, Idaho.

[Abbreviations: RMSE, root-mean-square error; $A E$, average error; $K_{\text {sat }}$, saturated hydraulic conductivity]

\begin{tabular}{llllc}
\hline & $\begin{array}{c}\text { Winfield } \\
\text { model } \\
\text { (2005) }\end{array}$ & $\begin{array}{c}\text { Pudney } \\
\text { model } \\
\mathbf{( 1 9 9 4 )}\end{array}$ & $\begin{array}{c}\text { Linear fit 1 } \\
\text { (10 samples) }\end{array}$ & $\begin{array}{c}\text { Linear fit 2 } \\
\text { (17 samples) }\end{array}$ \\
\hline $\begin{array}{c}\text { RMSE (in terms } \\
\left.\text { of log } K_{\text {sat }}\right)\end{array}$ & 1.99 & 2.06 & 2.86 & 1.96 \\
$\begin{array}{c}A E(\text { in terms } \\
\left.\text { of } K_{\text {sat }}\right)\end{array}$ & -0.1110 & -0.0009 & -0.0034 & 0.0001 \\
\hline
\end{tabular}

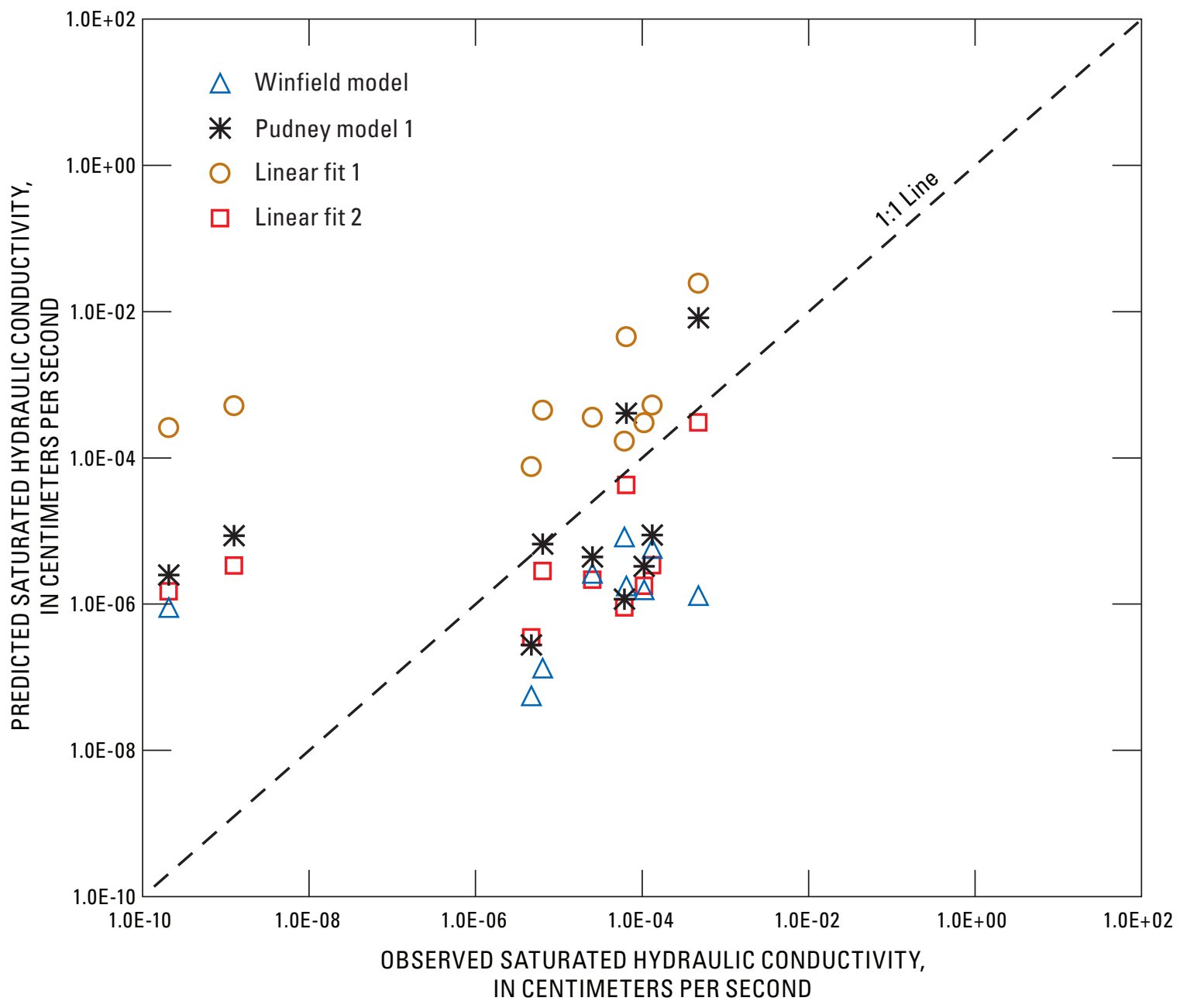

Figure 8. Relation between predicted and observed saturated hydraulic conductivity for the Winfield model, the Pudney model, a linear model fit to the data from this study (linear fit 1), and a linear model fit to the data from this study and the deep samples from Pudney (1994) (linear fit 2), Idaho National Laboratory, Idaho. The line represents a 1:1 relation. 


\section{Summary and Conclusions}

Knowledge of $K_{\text {sat }}$ and other parameters are required as input to the numerical models of saturated flow and transport which commonly are used as tools in risk assessment. $K_{\text {sat }}$ and bulk properties were measured for 10 core samples from sedimentary interbeds within the ESRP aquifer and estimated using the Winfield site-specific property-transfer model and a simple linear relation between $K_{\text {sat }}$ and $\rho_{\text {bulk }}$. The multiple linear-regression property-transfer model for estimating $K_{s a t}$ from more easily measured $\rho_{\text {bulk }}$ and particle-size distributions originally was developed for sedimentary interbeds of the unsaturated zone at the INL. The Winfield regression model, which yielded estimates comparable to a simple linear relation between $K_{\text {sat }}$ and $\rho_{\text {bulk }}$, systematically under predicted $K_{\text {sat }}$ likely due to $\rho_{\text {bulk }}$ values being higher for the aquifer samples than for the samples from the unsaturated zone upon which the model was developed. Because the aquifer samples are affected by different processes than those from the unsaturated zone, such as greater overburden pressure and constant saturated flow, the addition of explanatory variables that include mechanical, chemical, and mineralogical information with a multiple linear-regression approach might yield better predictions. The data presented here provide information useful in refining the hydraulic influence of sediments in the current subregional scale ground-water flow model either by scaling existing values for each of the three units in the model or by explicit incorporation of sedimentary units.

\section{Acknowledgment}

The author thanks Joseph Rousseau, Supervisory Hydrologist, U.S. Geological Survey, for his continued support of this work.

\section{References Cited}

Ackerman, D.J., Rattray, G.W., Rousseau, J.P., Davis, L.C., and Orr, B.R., 2006, A conceptual model of ground-water flow in the eastern Snake River Plain aquifer at the Idaho National Laboratory and vicinity with implications for contaminant transport: U.S. Geological Survey Scientific Investigations Report, 2006-5122, 62 p. Available at http:// pubs.usgs.gov/sir/2006/5122/

Anderson, S.R., 1991, Stratigraphy of the unsaturated zone and uppermost part of the Snake River Plain aquifer at the Idaho Chemical Processing Plant and Test Reactors Area, Idaho National Engineering Laboratory, Idaho: U.S. Geological Survey Water-Resources Investigations Report 91-4010, 71 p.
Anderson, S.R., and Lewis, B.D., 1989, Stratigraphy of the unsaturated zone at the Radioactive Waste Management Complex, Idaho National Engineering Laboratory, Idaho: U.S. Geological Survey Water-Resources Investigations Report 89-4065, 54 p.

Anderson, S.R., and Liszewski, M.J., 1997, Stratigraphy of the unsaturated zone and the Snake River Plain aquifer at and near the Idaho National Engineering Laboratory, Idaho: U.S. Geological Survey Water-Resources Investigations Report 97-4183, 65 p.

Anderson, S.R., Liszewski, M.J., and Ackerman, D.J., 1996, Thickness of surficial sediment at and near the Idaho National Engineering Laboratory, Idaho: U.S. Geological Survey Open-File Report 96-330, 16 p.

Barraclough, J.T., Lewis, B.D., and Jensen, R.G., 1981, Hydrologic conditions at the Idaho National Engineering Laboratory, Idaho_Emphasis 1974-1978: U.S. Geological Survey Water-Supply Paper 2191, 52 p.

Gee, G.W., and Or, D., 2002, Particle-Size Analysis: in Dane, J.H., and Topp, G.C., eds., Methods of soil analysis. Part 4-Physical methods: Madison, Wis., Soil Science Society of America, Soil Science Society of America Book Series 5, p. 255-293.

Hackett, B., Pelton, J., and Brockway, C., 1986, Geohydrologic story of the eastern Snake River Plain and the Idaho National Engineering Laboratory: U.S. Department of Energy, Idaho Operations Office, Idaho National Engineering Laboratory, 32 p.

Liszewski, M.J., and Mann, L.J., 1992, Purgeable organic compounds in ground water at the Idaho National Engineering Laboratory, Idaho-1990 and 1991: U.S. Geological Survey Open-File Report 92-174, 19 p.

Nimmo, J.R., and Mello, K.A., 1991, Centrifugal techniques for measuring saturated hydraulic conductivity: Water Resources Research, v. 27, p. 1263-1269.

Nimmo, J.R., Perkins, K.S., and Lewis, A.M., 2002, Steadystate centrifuge [simultaneous determination of water transmission and retention properties], in Dane, J.H., and Topp, G.C., eds., Methods of soil analysis. Part 4-Physical methods: Madison, Wis., Soil Science Society of America, Soil Science Society of America Book Series 5, p. 903-916.

Perkins, K.S., 2003, Measurement of sedimentary interbed hydraulic properties and their hydrologic influence near the Idaho Nuclear Technology and Engineering Center at the Idaho National Engineering and Environmental Laboratory: U.S. Geological Survey Water-Resources Investigations Report 03-4048, 19 p. 
Perkins, K.S., and Nimmo, J.R., 2000, Measurement of hydraulic properties of the B-C interbed and their influence on contaminant transport in the unsaturated zone at the Idaho National Engineering and Environmental Laboratory, Idaho: U.S. Geological Survey Water-Resources Investigations Report 00-4073, 30 p.

Pudney, W., 1994, Physical properties of sediments affecting saturated vertical water flow at the Idaho National Engineering Laboratory: Idaho State University Department of Geology, Master’s Thesis, 92 p.

Reynolds, W.D., Elrick, D.E., Youngs, E.G., Amoozegar, A., Bootlink, H.W.G., and Bouma, J., 2002, Saturated and field-saturated water flow parameters, in Dane, J.H. and Topp, G.C., eds., Methods of soil analysis. Part 4-Physical methods: Madison, Wis., Soil Science Society of America, Soil Science Society of America Book Series 5, p. 802-816.

Welhan, J.A., Farabaugh, R.L., Merrick, M.J., and Anderson, S.R., 2006, Geostatistical modeling of sediment abundance in a heterogeneous basalt aquifer at the Idaho National Laboratory, Idaho: U.S. Geological Survey Scientific Investigations Report 2006-5316, 32 p. Available at http:// pubs.usgs.gov/sir/2006/5316/
Winfield, K.A., 2003, Spatial variability of sedimentary interbed properties near the Idaho Nuclear Technology and Engineering Center at the Idaho National Engineering and Environmental Laboratory, Idaho: U.S. Geological Survey Water-Resources Investigations Report 03-4142, 36 p. Available at http://pubs.usgs.gov/wri/wri034142/

Winfield, K.A., 2005, Development of property-transfer models for estimating the hydraulic properties of deep sediments at the Idaho National Engineering and Environmental Laboratory, Idaho: U.S. Geological Survey Scientific Investigations Report 2005-5114, 49 p. Available at http://pubs.usgs.gov/sir/2005/5114/

Zar, J.H., 1996, Biostatistical analysis ( $3^{\text {rd }}$ ed.): Upper Saddle River, N.J., Prentice Hall, Inc., [variously paged]. 
This page intentionally left blank. 
Manuscript approved for publication, August 26, 2008

Prepared by the USGS Publishing Network

Robert Crist

Bill Gibbs

Debra Grillo

Bobbie Jo Richey

Sharon Wahlstrom

For more information concerning the research in this report, contact the Director, Idaho Water Science Center

U.S. Geological Survey, 230 Collins Road

Boise, Idaho 83702

http://id.water.usgs.gov 


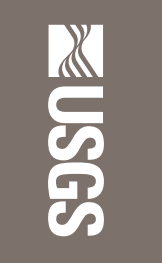

맘

产.

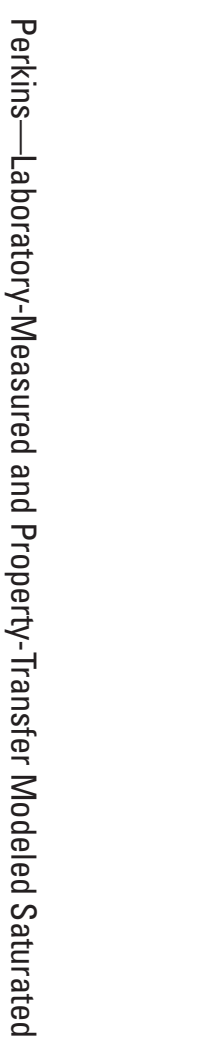

